\title{
PIEŠIMAS ARCHITEKTŪROJE - NUO VAIZDAVIMO IKI KŪRYBOS
}

\author{
Edita Riaubienè \\ Architektūros pagrindų ir teorijos katedra, Vilniaus Gedimino technikos universitetas, \\ Pylimo g. 26/Trakug. 1, 01332 Vilnius, Lietuva \\ El.paštasedita.riaubiene@vgtu.lt \\ Iteikta 20101108
}

Santrauka. Studiją inspiravo skirtingų laikotarpių mąstytojų (E. L. Boullee, Cl. N. Ledoux, J. Ruskin) išsakoma mintis, kad nebūdamas tapytoju ar skulptoriumi, negali būti architektas. Siekiant rasti paaiškinimą, kas lemia tokią vaizduojamųjų menų ir architektūros priklausomybę, žiūrima į meno suvokimo istorinę raidą, kur išryškẻja vaizduojamụjų menų ir architektūros santykio esminiai aspektai. Tyrime aptartos Renesanso, Apšvietos ir šių laikų teoretikų ižvalgos bei nuomonès išryškino piešimą kaip šių menų jungiančią grandį ar net pagrindą. Alberti nurodo, kad iš tapytojo architektas turi perimti gebejjimą suvokti ir vaizduoti realybę - „suvokimo linijas“, kurios architektūroje tampa naujos realybès kūrimu - „kūrimo linijomis“. Nuo XVII a. išsiplečia piešimo reikšmé, kai jis tampa minčių atskleidimo, vaizdo perteikimo priemone. Piešimą apibrěžus kaip mąstymo formą, pirmine jo savybe galima ịvardinti galimybę numatyti būsimą architektūrinio objekto rezultatą, bet ne mažiau svarbus piešimas kaip ịkvepianti jèga ar formos radimosi eigos fiksavimas, aprẻpiantis visas, net ir prieštaringas kūrybinio proceso apraiškas. Tyrẻjai nurodo piešimą kaip discipliną, esančią tarp vaizdavimo ir kūrybos, ir tai suponuoja mintį, kad piešimas yra viena tinkamiausių priemonių architektūrai modeliuoti. Piešimą suvokus kaip veikimą ir darymą, randasi prielaidų naujoms patirtims ir naujoms mintims, kurios dar labiau akcentuoja piešimo svarbą architektūrai.

Reikšminiai žodžiai: architektūra, vaizduojamieji menai, tapyba, meno sąvoka, disegno, vaizdavimas, piešimas - mąstymo būdas.

\section{Ivadas}

Paskata aiškinantis architektūros ir vaizduojamųjų menų sąsajas buvo John Ruskin tezè, kad „nebūdamas puikiu skulptoriumi ar tapytoju, negali būti architektas. Jei tu nei skulptorius, nei tapytojas, tai tegali būti tik statytoju“". Šią mintị palaikè ir Etienne-Louis Boullee (1728-1799) ir Claude Nicolas Ledoux (17361806), teigęs, kad ,jei nori būti architektas, pradèk kaip tapytojas“ (Kruft 1994). Taigi kyla klausimas, kur slypi tokių teiginių priežastys, kas lemia vaizduojamųjų menų pirmumą ir būtinybę architektūros atžvilgiu. Pirmiausia pateikiama meno reiškinio suvokimo rai-

\footnotetext{
${ }^{1}$ John Ruskin: „<...> a great architect must be a great sculptor or painter. No person, who is not a great sculptor or painter can be an Architect. If he is not a sculptor or painter, he can only be a builder“. Pagal Ruskin (2009).
}

dos panorama, kurioje išryškejja architektūros ir vaizduojamųjų menų sąvokos kaita ir jų santykio esminiai aspektai. Toliau analizuojami Renesanso, Apšvietos ir šių laikų teoretikų darbai ir įžvalgos, kurios nedviprasmiškai atskleidžia piešimą kaip tiriamųjų menų sąsajų esmę. Piešimo kaip vaizdavimo medijos ir minčių generavimo architektūros kūrybiniame procese esmè išryškinama remiantis išsamiais W. Tatarkievicz tyrimais (2007), L. B. Alberti traktatais apie tapybą ir architektūrą $(1970,1988)$ ir jų sugretinimu, atliktu tyrejjo W. Arbizu (2007); taip pat tyrejjų R. Evans (1997), S. Milani (2007) ir Segui De La Riva (Grau 2006) atliktais ir paskelbtais darbais. 


\section{Architektūros ir vaizduojamųjų menų suvokimo raida}

Menas Senovès Graikijoje (techne), Romoje, viduramžiais (ars) ir dar naujųjų amžių pradžioje, t. y. Renesanso epochoje reiškè gebèjimą, mokejjimą kurti daiktus pagal taisykles, dèsnius. Darymas ne pagal dèsnius, o ịkvejpimą, fantaziją reiškè priešybę menui (Tatarkievicz 2007). Menas antikoje ir viduramžiais apèmè amatus ir mokslus (mokẻjimą gaminti, taisyklių žinojimą, profesines žinias), ir jie buvo skiriami pagal fizinio bei protinio darbo reikalavimus ị mechaniškuosius (vulgares) ir laisvuosius (liberales). Nors architektūra ir kiti vaizduojamieji menai patenka ị mechaniškujų menu grupę, bet Platonas, klasifikuodamas menus, atskiria kuriančius tikrovę (architektūra) ir pamègdžiojančius ją (tapyba) ${ }^{2}$.

Viduramžiais ars suprastas kaip tobulesnis menas, todèl skiriami 7 laisvieji menai: gramatika, retorika, logika, aritmetika, geometrija, astronomija, muzika (muzikologija), kurie iš tiesų yra mokslai šiandienine samprata. Mechaniškuosius menus bandyta simetriškai sugretinti su laisvaisiais ir todèl taip pat skiriami 7, bet jų iš tiesų yra žymiai daugiau, todèl į šį riboto skaičiaus sąrašą ịtraukti tik patys svarbiausieji ${ }^{3}$. Mechaniškųju menų sąraše iš mūsų šiandien suvokiamų menų tèra tik architektūra. O kur gi tapyba ir skulptūra? Šie menai nebuvo paminèti nei vienoje iš menų grupių, bet, matyt, vis tiek buvo suprantami kaip menas, t. y. mokejjimas gaminti laikantis tam tikrų taisyklių. Vaizduojamieji menai ị mechaniškųjų grupès septynetą nepateko, nes neatlaike to meto menams ypač svarbaus naudos kriterijaus. Taigi galima teigti, kad viduramžių mene vaizdavimo aspektas menkai vertintas.

Renesanso epochoje akcentuotas grožis ir jo kūrejjas, tai lëmè tam tikrus meno sąvokos struktūrinius pokyčius. Plastiniai menai (dailieji) palaipsniui atsiskyrè nuo amatų (mechaniškujų menų) ir tapo laisvaisiais menais (mokslais). Tai logiška, nes Renesanso menininkų idealu tapo su jų darbu susijusių dèsnių tobulinimas, matematiškai tikslių kūrinių formavimas. Vienijančia plastinių menų - skulptūros, tapybos ir architektūros - idejja tapo piešimas, kuris ir nulèmè „piešimo menų“ (arti del disegno) pavadinimą ir sąvoką.

\footnotetext{
${ }^{2}$ Platonas dar patikslino šio atskyrimo argumentus ir teigè esan menus, kuriančius realius daiktus ir kuriančius daiktų vaizdus.

${ }^{3}$ Viduramžiais skirti 7 mechaniškieji menai: 1) žmonèms duodantys maista, 2) skirti jiems rengti, 3) suteikiantys jiems būstą, 4) aprūpinantys transporto priemonemis, 5) gydantys ligas, 6) mokejjimas mainikauti ir 7) mokejjimas gintis nuo priešo.
}

Šiuo menų sąvokos performavimo laikotarpiu iškilo keletas skirtingų požiūrių ${ }^{4}$. Vaizduojamieji menai (tapyba, skulptūra) ir architektūra patenka ị laisvųjų menų grupę, bet jos viduje neretai atskiriami dèl realybę kuriančio ar ją mègdžiojančio prado; dèl naudingumo ar malonumo suteikimo ${ }^{5}$, t. y. dèl skirtingų priemonių ir tikslo.

XVII a. menų ir amatų atskyrimą argumentavo menams priskiriamas poetiškumas, t. y. perkeltinè prasmé, metafora. F. Blondel anksčiau vadintus tauriaisiais, intelektualiaisiais, o vèliau tapusius dailiaisiais menus ${ }^{6}$ vertino dèl jų harmoningumo, kuris teikia mums malonumą. Charles Batteux (1747) $)^{7}$ suformulavo ir ittvirtino dailiujų menų terminą; suminejo penkis dailiuosius menus: tapybą, skulptūrą, muziką, poeziją, šokị ir du jiems artimus - tai architektūrą ir iškalbą. Taigi menai vèl iggavo magiško septyneto išraišką $(5+2=7)$, kur pagrindinejje grupejje buvo tapyba ir skulptūra, o jai artimoje - architektūra. Vaizduojamieji menai priklausè grupei, kurios tikslas buvo mégdžioti gamtą, patikti, teikti malonumą, o architektūra atsidūrè tarpiniame pogrupyje, kurio tikslas buvo dvejopas - teikti naudą ir malonumą. Dailiųjų menų teorijos pagrindą sudare teiginys, kad jų bendras bruožas yra pamègdžiojimas. Čia galima pastebèti tam tikrą analogiją su antikoje buvusiu dalinimu i kuriančiuosius ir pamègdžiojančiuosius menus ${ }^{8}$. C. Batteux pamėgdžiojimo savybę priskyrè visiems dailiesiems menams, nors tai visai netiko muzikai ir architektūrai. Šiuo momentu ypač akcentuojama architektūros kuriančioji

\footnotetext{
${ }^{4}$ Laisvųjų menų: gramatikos, retorikos, poezijos, tapybos, architektūros, muzikos jungtis buvo ịžvelgta muzikoje, nes ši ịkvepia visus kitus kūrejjus: poetus, skulptorius, architektus, todèl šių menų vienijančiais bruožais laikytas melodingumas, ritmiškumas. Poezija, tapyba, skulptūra ivardinta kaip tauriausiu jausmų ir didžiausių gabumų objektas; jiems būdingas patvarumas. Priešinant amatams, kurie kuria žmonems reikalingus daiktus, atskiriama tapyba, skulptūra ir poezija, kurianti daiktus, kad šie išliktų atmintyje. Tauriuosius ir atminties menus sieja vaizdingumas, naudojimasis konkrečiais vaizdiniais, o ne abstrakcijomis. Matyt, dèl šios priežasties atminties menų grupejje neminima architektūra.

${ }^{5}$ Renesanso epochoje daug perimta iš antikos menų skirstymo; išliko laisvųjų ir paprastųjų menų (amatų) grupés, tik pakito jų turinys; dailieji menai priešinti amatams ir tapo laisvaisiais; laisvųjų grupejje išskirti naudingieji ir teikiantys malonumą, kuriantieji ir pamègdžiojantieji.

${ }^{6}$ Francais Blondel (1675) sudare šiu menu grupę: architektūra, poezija, iškalba, komedija, tapyba, skulptūra, muzika, šokis, ji ilgainiui sudarè dailiųjų menų sistemą.

${ }^{7}$ Charles Batteux $1747 \mathrm{~m}$. knygoje Les beaux arts reduits a un seul principe buvo aiškiai atskirti dailieji menai nuo mechaniškųjų, t. y. amatų.

${ }^{8}$ Tokio menų skirstymo požiūrio laikèsi Platonas ir Aristotelis. Platono menų klasifikacija pagrịsta menų santykiu su tikrove: vieni menai kuria tikrovę (architektūra), o kiti (tapyba) - mègdžioja ar atkartoja ją. Aristotelis tikslino tokią klasifikaciją, ịvardindamas menus, kurie papildo gamtą ir kurie pamėgdžioja ją.
} 
savybè, kontrastuojanti su tapybos pamėgdžiojančiąja (mimesis, imitatio).

XVIII a. tapo aišku, kad menas yra nei amatai, nei mokslai, ir esminius svarstymus čia analizuojamu klausimu išreiške I. Kantas (1991). Analogiškai Platonui skyrè tiesos ir apgaulès menus, kuriems nuosekliai atstovavo architektūra ir tapyba. Taip pat skyrè menus, kurie remiasi gamtoje egzistuojančiais daiktais (tapyba) ir kurie operuoja sukurtais daiktais (architektūra). Kantas išreiške ir savo originaliąją menų klasifikaciją, kurios pagrindą sudare meno rūšies priklausomybė nuo žmogaus gebejjimo rasti būdą, kaip išreikšti mintis ir jausmus. Diferencijuoti trys pagrindiniai būdai kurti meną tapo nuoroda ị tris meno rūšis - žodžius pasitelkia poezija ir iškalba, garsus - muzika, judesị - tapyba, skulptūra, architektūra. Pagal tokị skaidymą architektūra glaudžiai gretinama su kitais vaizduojamaisiais menais.

Apšvietos epochos menas, igijęs autonomiškumo, savo tikslu laikè malonumą ir grožị. Laikantis tokio suvokimo pirmenybè teikta vaizduojamajam aspektui mene, ir todèl visai pagrịstai šiuo metu nuskamba E. L. Boullee ir Cl. N. Ledoux frazès apie tapybos pirmumą architektūros atžvilgiu.

XIX a. meno termino reikšmé pakito, sumažèjo apimtis, todèl radosi nauja meno sąvoka, o dailiaisiais menais imta vadinti dar siauresnę menų grupę - t. y. plastiškuosius menus, kuriuos anksčiau vadino piešimo menu (tapyba, skulptūra, architektūra). Toks plastiškųjų menų atskyrimas nuo kitų menų pagrịstas suvoktu kūrybos dvilypumu, t. y. daiktų ir žodžių kūryba ${ }^{9}$ (Tatarkiewicz 2007: 83). Išryškèjo skirtumas tarp plastinio ir žodžio meno.

XIX a. antrojoje pusejje dailieji menai skirstyti įvairiai: į kuriančiuosius ir vaizduojamuosius, ị sukeliančius konkrečias asociacijas ir netikètas asociacijas, skirti figūriniai ir nefigūriniai menai. Ypač populiarus buvo skaidymas ì grynuosius ir taikomuosius menus; pagal tokị skaidymą architektūra atsiskyrè nuo kitų plastiškụjų (vaizduojamųjų) menų.

Menų grupavimas, remiantis sukeliamais pojūčiais, meno funkcija, atlikimo būdu, nauda, atskleide, kad menas visuomet dalijasi ị panašias grupes. Todèl galima numanyti, kad nèra tokios menų sistemos, kuri atitiktų visus reikalavimus (Tatarkiewicz 2007: 88). Kaip iliustracija tokiam nuogąstavimui gali būti tai, kad tapyba ir skulptūra, praradusios figūratyvumą, priartèjo prie architektūros ir tapo kuriančios, abstrakčios, keliančios

\footnotetext{
9 Toki skaidymą ryžtingiausiai argumentavo G. E. Lessing (1766), teigdamas, kad „tapyba kaip ir poezija naudoja ịvairius ženklus, tapybos ženklai - tai spalvos ir erdveje išdestytos figūros, o poezijos ženklai - laike artikuliuoti garsai. Tapybos ženklai yra natūralūs, poezijos - laisvai pasirinkti. Tapyba vaizduoja daiktus, esančius erdvèje, o poezija - daiktus, esančius laike“.
}

netikètas asociacijas. Todèl dabar abejotinas tapo skirstymas ị kuriančiuosius ir vaizduojamuosius menus.

Iki XIX a. buvo visuotinai pripažinta, kad menas reiškè kurti grožĭ, taigi menui keltas tik estetinis tikslas ${ }^{10}$. XX a. buvo suabejota sąvokos tinkamumu. Tapo sunku apibrèžti meno sąvoką, nes jam kelti ịvairūs, nepastovūs ir net prieštaringi kriterijai. Menas galèjo būti suvoktas kaip tikrovès vaizdavimas, formų konstravimas ar išgyvenimų išraiška, o kūrinys turèjo žavèti, jaudinti ar sukrèsti. Šiuolaikinis menas daugiareikšmis, todèl galimas tik alternatyvus apibrěžimas: menas konstruktyvus ir (ar) ekspresyvus, grindžiamas taisyklèmis ir (ar) temperamentu, techniškas ir (ar) metafiziškas. Pagal tradicinę sampratą vaizduoti yra tapybos prerogatyva, kurti - architektūros, o apmąstyti ir reikšti mintis bei išgyvenimus vienodai atitinka šiuolaikinès tapybos ir architektūros esmę. Galima būtų numanyti, kad dabartinè meno sąvoka išreiškia galimybę vaizduojamiesiems menams ir architektūrai ne tik reikšti jausmus bei mintis, bet ir tapti apmąstymų, pažinimo erdve.

\section{Piešimas - tikrovės vaizdavimas ir minčių vizualizavimas}

Meno sąvokos raida atskleidè architektūros ir vaizduojamụjų menų gretimybę Renesanso, Apšvietos ir dabartiniu laikotarpiu. Todèl siekiant išryškinti vaizdavimo aspektą architektūroje, aktualizuojant piešimo svarbą architektūros kūryboje, remiamasi didžiųjų mąstytojų, meno teoretikų, nagrinèjusių vaizduojamajj meno pobūdị, mintimis.

L. B.Alberti traktatai apie tapybą (1970) ir architektūrą $(1988)^{11}$ turejo didelès svarbos ne vien ankstyvajame Renesanse. Tai pirmoji teoriné diskusija apie tapybą ir pirmoji knyga po Vitruvijaus ${ }^{12}$, atgaivinusi dialogą apie architektūrą. Knygos radosi skirtingu laiku, todèl jas gretinant galima pastebèti autoriaus interesų kaitą ir įdomių sankirtų tiriant piešimą. Šiuose veikaluose bendra yra tai, kad autorius piešimą analizuoja kaip tikrovès suvokimą ir jos vaizdavimą (Arbizu 2007).

Alberti rašo, kad ,architektui naudingi ir gyvybiškai reikalingi menai - tai tapyba ir matematika", taip pat jis teigia, kad architektui užteks ịsisąmoninti tuos tapybos elementus, kurie yra aprašyti traktate Della pittura. Bet galima numanyti, kad i tuos elementus nèra įtrauktas spalvos naudojimas ar perspektyvinio piešinio naudingumas (Arbizu 2007). Siekiant argumentuoti tokị spejji-

\footnotetext{
${ }^{10}$ Tai atitiko šūkị „menas menui“: „Tikrasis grožis yra tas, kuris netarnauja niekam. Viskas, kas yra naudinga, yra bjauru“ (T. Gautier, 1834).

${ }^{11}$ Leon Battista Alberti, Della Pittura (1435-36); De re aedificatoria (1443-52).

${ }^{12}$ Vitruvius De architectura libri decem (2006).
} 
mą, galima pasiremti Alberti požiūriu, kad tapyba turi netiesos savybių, nes „vaizduojamas modelis tapybos priemonemis aprengiamas žavinčiai ir viliojančiai, o tai nèra architekto tikslas ar ketinimas perteikiant faktus“. Kaip netiesos elementas pripažistama ir perspektyvinè linija tapyboje, o ortogonalūs brèžiniai vertinami kaip teisingi architekto piešiniai ${ }^{13}$. Tuomet kyla klausimas, tai ką gi architektas turi žinoti apie tapybą? Galvojant apie tapybą ir architektūrą, natūraliai ịsivaizduojama geometrija ir jos naudojimas, nes abiejuose Alberti veikaluose aptinkama nuolatinių maldavimų naudoti geometriją: „tvirtinu, kad būtina tapytojui mokèti geometriją“, čia pat pateikiami linijų ir kampų apibrèžimai (Alberti 1970). Alberti daug dèmesio skiria kontūrui, kuris tapyboje apibrèžia formą, o architektūroje - tūrius ir erdvę; taigi linija suvokiama kaip būtina tapybos ir architektūros sąlyga, be kurios negali veikti matymo mechanizmas. Traktate apie tapybą autorius aiškina, kad matoma spinduliais, linijomis, plokštumomis; ir kai suprantamos „suvokimo linijos“, kurios padeda konstruoti abstraktuc pasaulio įvaizdi, galima sakyti, kad taip atrandamos ir „kūrimo linijos“. Tik iggavęs naujų priemonių architektas gali įsivaizduoti architektūros modifikacijas. Taigi iš tapybos perimtos „suvokimo linijos“ leistų architektui jas naudoti kaip priemonę kūrybai.

Alberti požiūris į architekto piešimą, t. y. braižymą, yra esminis vizualumo požiūriu ir, matyt, pirmą kartą pateikiami architektūrinio vaizdavimo principai, kai planas, fasadai ir pjūviai susiejami ị nuoseklią erdvinę sistemą. Taigi linkstama prie ižžalgos, kad jei piešiant galima vaizduoti esamą aplinką - tikrovę, tai taip pat egzistuoja galimybe vaizduoti dar nesančią aplinką tokiu pat būdu. Pritarus šiai minčiai, piešimas tampa galimybe ir priemone generuoti naują realybę. Nors tai novatoriška mintis, bet dar nedrąsiai žiūrima it „,kūrimo liniju“" naudojimą.

Alberti, aiškindamas apie kontūrus ir tinklelius, nurodo it „nematomas linijas“ (Alberti 1970), matyt, nori, kad architektas tai perimtų iš tapybos. Čia pastebimas projekciniam piešimui būdingas „kryptingumas“, pagal kuri perspektyva tampa sutvirtinanti ir susisteminanti išorinị pasaulị (Arbizu 2007). Tai galètų paaiškinti Alberti teigini, kad „imanoma suprojektuoti visas formas mintyse be jokių materialių dalykų, pažymint ir nustatant ịvairių linijų ir kampų fiksuotas kryptis bei jungtis“. Minties ir materijos tema aptinkama visame De re aedificatoria tekste. Autorius teigia, kad ,visas pas-

\footnotetext{
${ }^{13}$ L. B. Alberti De re aedificatoria rašo: „skirtumas tarp tapytojo piešimo ir architekto piešimo yra šis: pirmasis daug stengiasi, kad pabréžtų daiktų reljefiškumą naudodamas šviesotamsą, nykstančias linijas ir kampus; architektas atmeta šešèlius, bet naudoja projekcijas (pradedant nuo plano), nekeičia ir neperdirba linijų, išlaiko tikrus kampus, atskleidžia kiekvienos šoninès projekcijos dydị ir formą".
}

tatas susideda iš lineamenta ir struktūros" (materialios konstrukcijos); lineamenta galima būtų versti kaip „proto linijos" ar „minčių linijos“. Taigi Alberti teigia, kad architektūra susideda iš minties (idèjos) ir medžiagos, paimtos iš gamtos, tarpininkaujant gabiam ir išprususiam architektui. Tai analogiška Vitruvijaus teiginiui, $\mathrm{kad}$ „menas susideda iš dviejų dalykų“ realaus daikto (opus) ir jo teorijos (ratiocinatio). Alberti meną aiškina kaip teoriją ir mintị, išreikštą linijų forma.

Alberti dèmesys nuo suvokimo pereina it sumanymą. Della Pittura jis tapytojams siūlo dirbti vien su matymo sritimi. Tapytojas dirba vien su tuo, kas yra matoma, todèl jam draudžiama išradinèti ir prigalvoti, nurodant, kad „visuomet tai, ką nori nutapyti, yra paimta iš gamtos $^{\text {“" }}{ }^{14}$. Autoriaus požiūriu, reali ir pavaizduota erdvè yra tapačios. $\mathrm{O}$ architektūroje Alberti nustato minties erdvę ir realią erdvę bei galimybę konceptualiai perkelti idejjas ir objektus tarp jų. Lineamente ir turinys (kaip mąstymo produktas) bei visa kita, paimta iš gamtos, sujungiama kuriant architektūrą. Pasak Robin Evans (1997), architektūrinis piešimas (braižymas) užima pačią neaiškiausią ir labiausiai svarstytiną poziciją kelyje tarp idejos ir daikto. Alberti, matyt, pirmasis pastebëjo, kad šis kelias turi specifinių savybių ir gal dèl šios priežasties jis siūlè architektūrai suteikti aukštesnị statusą, nes architektai kuria nauja, o tapytojai tik mato ir atgamina jau egzistuojančius dalykus. Alberti raštai sudare teorini pagrindą iš tapybos srities perimti „,suvokimo linijas“ ir gebejjimą vaizduoti tikrovę, kad tai pagal analogiją būtų naudinga architekto „kūrimo linijų“veikimui, formuojant architektūrą.

Iki XV a. laikytas amatininko reikalu, vèliau piešimas tapo vaizduotés projektavimo dalyku. L. B. Alberti pirmasis teoriškai suformulavo piešimo ir architektūros sąryšį ir piešimas nebebuvo vien menininko grafinè priemoné, bet tapo lauku, kur tobulinama ideja. Žinoma, Alberti atidžiai analizavo praktinius piešinio-brèžinio atlikimo aspektus, svarstè, kad perèjimas nuo idejjos iki rankos, kuri piešia, yra sudètinga, pilna kliūčių kelionè ir „čia menininkas klajoja tarsi aklas“ (Alberti 1970). Leonardas da Vinčis (1452-1519) piešimą laikè įkvejpimu ir jị priskyrè intelektualiai veiklai ${ }^{15}$. GiorgioVasari (1511-1574) laikais piešimo triumfas kilo iš to, kad buvo įveiktas ankstesnis negebejjimas ir negalejjimas atvaizduoti tai, kas buvo ịsivaizduota ar su-

\footnotetext{
${ }^{14}$ Iš tapytojo reikalaujama aiškiai ir vientisai suvokti kompoziciją, kurią nori nutapyti: „neimk pieštuko ar teptuko ị rankas, kol nesi mintyse sudaręs vaizdo, ką nori tapyti ir kaip tapyti“ (Alberti 1970).

${ }^{15}$ Leonardas piešimą laike „švaraus meno“ studija, atskirdamas nuo tapymo ir rašymo ir pateikdamas kaip kontrastą su „nešvariais menais" - skulptoriaus veikla.
} 
galvota $^{16}$. Visgi XVI a. meno akademijos savo mokymą rèmé piešimu, o pagrindiniu siekiu buvo menininkas, pirma mokomas būti tapytoju (atvaizdavimo meistru), o tik paskui architektu (Milani 2007).

Renesanso meistrai menu pagrindu ir ištakomis laikè piešimą, o G. Vasari dar sutvirtino šią nuostatą suformuluodamas arti del disegno (piešimo menų) sąvoką. Ši sąvoka sujungia tris menus: tapybą, skulptūrą, architektūrą pagal bendras ištakas - piešimą, kuri Vasari laikè menų tèvu ${ }^{17}$ (Vasari 2000).

Ilgainiui piešimas tapo idejų plètojimo pagrindu. Tokį piešimo sureikšminimą ar net suabsoliutinimą galima matyti XVI a. italų tapytojo ir architekto F. Zuccari (1542-1609) darbe ${ }^{18}$ apie tapybą, skulptūrą ir architektūrą, kur jis jau nebedare skirtumo tarp piešimo ir idèjos, o formulavo disegno interno (vidinis piešimas) ir disegno esterno (išorinis piešimas) sąvokas, nuosekliai atitinkančias idèją ir jos išraišką. Zuccari požiūriui būdingas svarbus dalykas, kad žmogus turi suteikti reikšmę ir formą išoriniam pasauliui. Prielaida, kad disegno interno ịsivaizduojama dvasinè idèja tampa žinoma, suteikia piešimui pažintinę reikšmę ir statusą, t. y. piešimas tampa priemone, padedančia generuoti žinias ir tiesiog „tiesą“. Taigi piešimas atsiskleidžia kaip galimybè būti mūsų pasaulio supratimo, pažinimo dalimi ${ }^{19}$. Tyrejas Milani (2007) svarsto, kad perejjimas nuo disegno interno i̇ disegno externo nèra savaiminis, intuityvus ar vykstantis dèl nepaaiškinamo nušvitimo (prisimenant Alberti frazę „klajoja tarsi aklas“). Tai greičiau konstruktyvus procesas, kai naudojamos loginès operacijos, kurios idejoms suteikia konkretesnę eigą. Kai einama nuo idejos link piešinio materializavimo, naudojame susitarimus, ženklus, kodus. Bet kodų naudojimas nèra tikslus ir objektyvus, randasi nukrypimų tarp kodo objektyvumo ir subjektyvaus jo panaudojimo. Piešinys dažnai išreiškia menini architekto požiūrị i savo kūrinị. Ženklo naudojimo būdas nulemia jo unikalumą; kaip menininkas panaudoja tą ženklą, taip atsispindi kūrèjo asmenybè.

Einant nuo idejjos link ịvaizdžio vien gebẻjimo piešti jau nepakanka; architektui reikia tam tikro tarpininka-

\footnotetext{
${ }^{16}$ Renesanse tapybos piešimas ir architektūros piešimas buvo netapatūs dalykai. Dèl projekto rengimo metodikos meninis piešimas nebuvo priskiriamas architektūrai. Taigi egzistavo tam tikras negebejimas ant popieriaus fiksuoti tai, kas buvo i̇sivaizduota, bet buvo išskirtinis gebejimas kopijuoti esančius objektus ar kitus piešinius.

${ }^{17}$ Giorgio Vasari $1562 \mathrm{~m}$. Florencijoje ịkūrè piešimo akademiją.

${ }^{18}$ Pagal S. Milani (2007); Federico Zuccari "L“idea de“ Pittori, Scultori et Architetti“, 1607, Turin.

${ }^{19} \mathrm{Jau}$ XIX a. filosofas Kondar Fiedler (1841-1895) darbe On judging works of visual art (vertimas 1949) svarste, kad menininkai kurdami meną psichiniame procese naudoja specifinị meninị pažinimą, kuris skiriasi nuo abstraktaus sąvokinio pažinimo. Taigi menine veikla tampa atskira mąstymo ir pažinimo forma.
}

vimo lauko, per kurị vaizduote filtruojama, kol ji sutiks atvaizdavimo priemonę (pieštuką, teptuką ar kompiuterị). Šioje tarpinèje diskursyvinëje erdvejeje ${ }^{20}$ autonomišku vaizdinių užuomazgoms nustatomi dialektiniai, dažnai prieštaringi formų santykiai ir tuo pat metu būdas, kaip jos bus pripažintos. Šis normavimo būdas orientuoja tiek išorini, tiek ir vidini piešinị (Milani 2007).

Šiuo atveju disegno interno nèra suvokiamas kaip narcizistinis konteineris, bet jis yra atviras visoms vertèms, kurios apima daugiau nei vieną subjektą (kūrèją). $\mathrm{XX}$ a. architektūros kūryba tapo vis labiau orientuota i̇ asmenybę ir šios žymejjimo sistemos (sutartiniai ženklai, simboliai) darosi vis svarbesnès, o išraiškos vis skirtingesnès ${ }^{21}$.

Pirmine piešinio kaip mąstymo formos savybè yra ne vien galimybẻ nuspèti būsimo statinio rezultatą, bet gal net dar svarbesnè savybė yra ta, kad piešinys tampa varomaja įkvépimo jèga (taip kalbejo ir Leonardas). Piešinys išsaugo ir asmeniškumo dimensiją, nes fiksuoja kūrèjo mąstymo etapus, žymi nuorodas ị skirtingų ir net prieštaringų minčių apraiškas, taip dokumentuoja formos radimosi procesą. Piešinys iggauna kūrybinès laboratorijos ir šio proceso fiksavimo reikšmę.

Madrido universiteto architektūros profesoriaus Fco Javier Segui 1974 m. atlikti tyrimai ${ }^{22}$ ir empiriniai stebèjimai patvirtino, kad gebẻjimas projektuoti architektūrą daugiausia priklauso nuo vizualios vaizduotés (figurative imagination), kitaip sakant, atminties ir vaizdinès fantazijos, vaizdų kūrimo ir išdèstymo (Grau 2006). Tyrejjas pastebi, kad piešimas egzistuoja visuose projektavimo etapuose, ir ši veikla yra priemoné, padedanti geriausiai konfigūruoti (apibrèžti ir išdèstyti) vaizdus, taip pat ji išlieka architektūrinio apmąstymo pagrindiniu momentu. Taigi piešimas tampa architektūros sandaros atskleidimo priemone, taip pat architektūros idejjų formavimo ir supratimo būdu. Galima teigti, kad piešimas kaip disciplina yra tarp vaizdavimo ir projektavimo (kūrimo), o tai iš esmès atitinka jau aptartą Alberti minties erdvę ir realią erdvę, F. Zuccari disegno interno ir disegno externo bei S. Milani schemą su tarpininkavimo erdve. Piešimas suvokiamas kaip pagrindinè formų mąstymo terpe ir tai pati tinkamiausia priemonè architektūriniam modeliavimui, nes architektas piešia ne vien aiškindamasis ar apibrëždamas erdves, bet ir kurdamas jas.

\footnotetext{
${ }^{20}$ Diskursyviné erdvé pagrịsta samprotavimu, kai sudaromos nuoseklios loginių grandžiu eilès.

${ }^{21}$ Tokios formų kūrimo sistemos gali būti aptinkamos daugelio architektų kūryboje: Le Corbusier 5 architektūros bruožai; apskrito pjūvio kolonos, kubas ir trikampe sija Aldo Rossi kūryboje; 9 kvadratų gardelè John Hejduk ir t. t.

${ }^{22} \mathrm{Fco} \mathrm{Javier} \mathrm{Segui} \mathrm{tyrimai} \mathrm{susiję} \mathrm{su} \mathrm{simuliavimo} \mathrm{ir} \mathrm{formalizavimo}$ procesais, taikomais architektūrai projektuoti. Pagal Javier Fco Raposo Grau (2006).
} 
Mintis, kad „sumanymas yra nupiešiamas“, jau yra tapusi esmine architektūrinejje veikloje. Tyrejjas P. Boudon ${ }^{23}$ architekto piešimo procese išskiria du momentus: pirmuoju vyksta kūryba, vertinimas, patikslinimas, pataisymas ir kt., o antruoju jau detalizuotas sumanymas tampa projektu ir šis pateikiamas užsakovui suprantama forma. Abu šie momentai yra komunikaciniai, nes operuojama nesamo, pakaitinio objekto ženklais. Pirmasis momentas yra tariamas, nes architektūrinis objektas egzistuoja tik virtualiai, kaip jis buvo bandomas konfigūruoti ir tokios apimties bei laipsnio, kokios autorius jị suvokè kaip galimą objektą, o antras momentas - sutartinis komunikacinis, nes atliekamas piešinys, siekiant pateikti vaizdą, atvaizduoti, taip jau konfigūruojamas idealus objektas. Tokia ,architekto piešimo" analizè tik dar kartą patvirtina, kad piešimas tampa mąstymo, tyrimo būdu, ir jis tinkamas ne vien tik kūrybiniam, bet analitiniam bei pažintiniam procesui. Čia sumenksta vaizduojamoji piešimo paskirtis, bet iškyla jo pažintinè, tyrimo ir kūrybinè esmè.

Ryškèjant kūrybinėms piešimo savybèms, tampa svarbūs žmogaus veiksmų tyrimai sociologiniu ir psichologiniu požiūriu, jie atskleidžia kiekvieną kūrybini procesą kaip ciklišką, kai tarp intuityvaus ir racionalaus prado atsirandanti itampa nuolat siekia pusiausvyros (Grau 2006). Šiuo požiūriu „darymas“ yra esminis, nes jis palaiko, didina patyrimą, kuris lemia žinojimą, taigi ir naujas mintis ${ }^{24}$. Piešimas irgi yra darymas, kai igyjamos įvairios patirtys, vyksta pažinimas, kyla naujų minčių, o tai reiškia, kad piešimas yra mąstymo ir minčių generavimo erdvè. Taigi remiantis analogija galima teigti, kad be piešimo kaip veikimo ar darymo, neatsiras naujų patirčių, kurios savo ruoštu galètų generuoti kitas naujas mintis. Todèl naujų minčių trūkumas neigiamai paveiks architektūrą.

\section{Apibendrinimai}

Tyrimas atskleidè, kad architektūrą ir vaizduojamuosius menus sieja piešimas. Alberti savo traktatuose apie tapybą ir architektūrą pastebi, kad iš tapytojo architektas turi perimti „suvokimo linijas“" (gebejimą suvokti ir vaizduoti realybę), kurios pagal analogiją architektūroje tampa „kūrimo linijomis“, t. y. naujos realybès kūrimu.

\footnotetext{
${ }^{23}$ P. Boudon $1984 \mathrm{~m}$. išspausdino straipsni „Schemos mastas“ parodos „Vaizdai ir isivaizduojama architektūra“ kataloge. Paroda organizuota Pompidou centre, Paryžiuje (L"Echele du Schemie. Images et imaginaires d"Architecture. Pompidou). Pagal Javier Fco Raposo Grau (2006).

${ }^{24}$ Kiekvienas ivykis, kiekvienas reiškinys nèra pats savaime, nèra izoliuotas, jis turi pirmtakus, ankstesnius patyrimus, kurie sukuria pasaulio ịvairių dalykų padarinius ir tuo pat metu pasaulis praturtinamas savo paties gamybos ir eksperimentų procese, kuris remiasi bandymais ir klaidų patyrimu.
}

Taigi nuo XV a. vidurio piešimas jau ne vien tik grafine vaizdavimo priemoné, o suvokiamas kaip idejos tobulinimo laukas. Alberti pabrèžia piešimą kaip sudètingą kelią, pereinant nuo idèjos prie jos iggyvendinimo.

Nuo XVII a. išsiplečia piešimo reikšmè, kai šis tampa idejos plètojimo ir realizavimo pagrindu. Tokie pokyčiai įvyko tik kai tapo įmanoma pavaizduoti sugalvotus ar įsivaizduotus dalykus. Taigi minties (disegno interno) atskleidimas, jos vaizdine raiška piešiniu ( $d i$ segno externo) suteikè piešimui pažintinę reikšmę, t. y. jis tapo pasaulio pažinimo, supratimo priemone.

Piešimą apibrěžus kaip mąstymo formą, pirmine jo savybe galima ịvardinti galimybę numatyti būsimą architektūrinio objekto rezultatą, bet ne mažiau svarbus piešimas kaip ịkvepianti jèga ar formos radimosi eigos fiksavimas, aprèpiantis visas, net ir prieštaringas kūrybinio proceso apraiškas. Visi aptarti tyrẻjai nurodo piešimą kaip discipliną, esančią tarp vaizdavimo ir kūrybos, ir tai suponuoja mintị, kad piešimas yra viena tinkamiausių priemonių architektūrai modeliuoti. Piešimą suvokus kaip veikimą ir darymą, iškyla prielaidų rastis naujoms patirtims ir naujoms mintims, kurios dar labiau aktualizuoja piešimo svarbą architektūrai.

\section{Literatūra}

Alberti, L. B. 1970. Della Pittura (1435-1436) [interaktyvus]. On Painting (translated by J. R. Spencer). New Haven: Yale University Press. 110 p. [žiūrèta 2010 m. birželio 25 d.] Prieiga per internetą: <http://www.noteaccess.com/Texts/ Alberti/>.

Alberti, L. B. 1988. De re aedificatoria (1443-1452). On the art of building in ten books (translated by Joseph Rykwert, Neil Leach and Robert Tavernor). Cambridge, Mass.: MIT Press. $420 \mathrm{p}$.

Arbizu, W. 2007. Architect of painting, painting of architecture. A comparison of L.B.Alberti"s "On Painting" and "On the Art of Building in Ten Books" [interaktyvus]. 7 p. [žiūrèta $2010 \mathrm{~m}$. rugpjūčio 3 d.]. Prieiga per internetą: <www.williamarbizudesign.com/Architect\%20of\%20Painting.pdf >.

Evans, R. 1997. Translations from drawing to building. Cambridge, MA: MIT Press. 294 p.

Grau, J. F. R. 2006. Thoughts about "architectural drawing" in the proccess of "designing" architecture, Espresion Grafica Arquitectonica (EGA) 11: 192-197.

Kantas, I. 1991. Sprendimo galios kritika. Vilnius: Mintis, 158-162.

Kruft, H. W. 1994. History of Architectural Theory. From Vitruvius to the Present. New York: Princeton Architectural Press. 705 p.

Milani, S. 2007. Theorethical bases regarding the relationship between drawings and architectural form, in the International conference "The role of the humanities in design creativity": Selected papers, University of Lincoln, UK [interaktyvus]. 9 p. [žiūrèta $2010 \mathrm{~m}$. rugpjūčio 7 d.]. Prieiga per internetą: <http://www.lincoln.ac.uk/home/conferences/human/papers/Milani.pdf $>$. 
Ruskin, J. 2009. Lectures of Architecture and Painting (1853), Bibliolife. $156 \mathrm{p}$.

Tatarkievicz, W. 2007. Šešiu sq̨vokų istorija. Vilnius: Vaga. 487 p.

Vasari, G. 2000. Žymiausiu tapytoju, skulptoriu ir architektu gyvenimai. Vilnius: Vaga. 455 p.

Vitruvius. 2006. De architectura libri decem. Ten books on architecture. Translation by Ingrid D. Rowland. New York: Cambridge University Press. 321 p.

\section{DRAWING IN ARCHITECTURE - FROM REPRESENTATION TO CREATION}

\section{E. Riaubienè}

Abstract. This analysis was inspired by the idea, expressed by the scholars (E. L. Boullee, Cl. N. Ledoux, J. Ruskin) that "no one can be an architect, as he isn"t a painter". To make clear what is the reason that makes these arts dependent and why visual arts have priority and necessity in architecture, a survey of the historic relations of these arts is made. The analysis incorporates the ideas, opinions and insights of scientists on the connections of architecture and visual arts. There drawing appears as the connector and even the background for these arts. Alberti affirms that an architect must adopt from a painter the competence to perceive and represent reality ("lines of percep- tion"), which in architecture can appear as the creation of new reality ("lines of creation"). Since the 17th c the significance of drawing increased, when it became the medium of describing and visualizing ideas. When drawing is defined as a form of thinking, its primary feature becomes the ability to anticipate the result of a prospective architectural object. But drawing is also very important as the driving force of inspiration or the stenography of the form-making process. Researchers interpret drawing as a discipline that is between the representation and creation; this notion affirms that drawing can be the best medium of modelling architecture. If drawing can be perceived as some kind of action and making, that will create preconditions for new experiences and new ideas that emphasize importance of drawing in architecture.

Keywords: architecture, visual arts, painting, concept of art, disegno, representation, drawing as the way of thinking.

\section{EDITA RIAUBIENE}

Dr, Assoc. Prof., Dept of Fundamentals and Theory of Architecture, Vilnius Gediminas Technical University (VGTU),

Pylimo g. 26/Traku g. 1, 01332 Vilnius, Lithuania.

E-mail: edita.riaubiene@vgtu.lt.

Doctor of the Humanities (architecture), VGTU, 2003. Research interests: history and theory of architecture, preservation of architectural heritage. 